\title{
Phylogenetic relationships within the Pylochelidae (Decapoda: Anomura: Paguroidea): A cladistic analysis based on morphological characters
}

\author{
RAFAEL LEMAITRE ${ }^{1}$, PATSY A. MCLAUGHLIN ${ }^{2} \&$ ULF SORHANNUS $^{3}$ \\ ${ }^{2}$ Smithsonian Institution, National Museum of Natural History, Department of Invertebrate Zoology, P.O. Box 37012, Washington, \\ D.C. 20013-7012, U.S.A. E-mail: lemaitrr@si.edu \\ ${ }^{2}$ Shannon Point Marine Center, Western Washington University, 1900 Shannon Point Road, Anacortes, Washington, 98221-9081B, \\ U.S.A.E-mail: hermit@fidalgo.net \\ ${ }^{3}$ Department of Biology \& Health Services, Edinboro University of Pennsylvania, Edinboro, Pennsylvania 16444, U.S.A. \\ E-mail: usorhannus@edinboro.edu
}

\begin{abstract}
Phylogenetic relationships within the "symmetrical" hermit crab family Pylochelidae were analyzed for 41 of the 45 species and subspecies currently considered valid. In the analyses, 78 morphological characters comprised the data matrix and the outgroup consisted of Thalassina anomala, a member of the Thalassinidae, and Munida quadrispina, a member of the Galatheidae. A poorly resolved strict consensus tree was obtained from a heuristic parsimony analysis of unweighted and unordered characters, which showed the family Pylochelidae and the subfamilies Pylochelinae and Pomatochelinae to be monophyletic taxa - the latter two groups had the highest Bremer support values. Additionally, while the subgenus Pylocheles (Pylocheles) was strongly supported, the subgenera Xylocheles, and Bathycheles were not. More fully resolved trees were obtained when using implied weighting, which recognized the monotypic subfamilies Parapylochelinae, Cancellochelinae and Mixtopagurinae. The subfamily Trizochelinae was found to have four distinct clades and several ambiguously placed taxa.
\end{abstract}

Key words: Decapoda, Anomura, Paguroidea, Pylochelidae, phylogenetic relationships

\section{Introduction}

Species of the family Pylochelidae Bate, 1888 are known as "symmetrical" hermit crabs because unlike their better known "asymmetrical" counterparts, most have symmetrical chelipeds, a pleon that is most often straight and provided with at least partially calcified, articulated tergites, paired pleopods, and generally symmetrical uropods. They are cryptic in habitat, living in pieces of wood, rocks, sponges, tusk shells, and rarely gastropods. Most of the 45 species and subspecies known from the world are distributed in tropical waters of the Indo-Pacific, with only three known from the western Atlantic; the species range in depth from 30 to $1570 \mathrm{~m}$ although they are most frequently found from 200 to $500 \mathrm{~m}$ (Forest 1987a, b).

The Pylochelidae were discovered in the late $19^{\text {th }}$ century when the first species, Pomatocheles jeffreysii Miers, 1879, was described. Miers placed this unique species in the Paguridea, but noted a mix of characters that led him to believe that $P$. jeffreysii established a "transition from the Paguridea to the Macrura" (Miers 1879: 50). As more "symmetrical" species were discovered (Fig. 1), this evolutionary view was maintained by other carcinologists (e.g., A. Milne-Edwards 1880; Bate 1888; Henderson 1888; Alcock 1905; Bouvier 1940) who allied these hermit crabs with thalassinideans or homarids. It was Bate (1888) who proposed the family Pylochelidae for these unusual hermit crabs, although he placed great importance on their gill structure and classified them in his division Trichobranchiata alongside Macrura with similar gill structure. Despite the evolutionary significance of pylochelids in deciphering hermit crab ancestry or even the Anomura, they were 
rarely mentioned in the scientific literature during the most of the $20^{\text {th }}$ century. Hermit crab classifications such as MacDonald et al.'s (1957), who considered hermit crabs as polyphyletic (Coenobitoidea and Paguroidea), or McLaughlin's (1983), who viewed hermit crabs as monophyletic (Paguroidea), placed pylochelids as a basal, primitive group. However, inter- and intrageneric relationships have remained poorly understood.

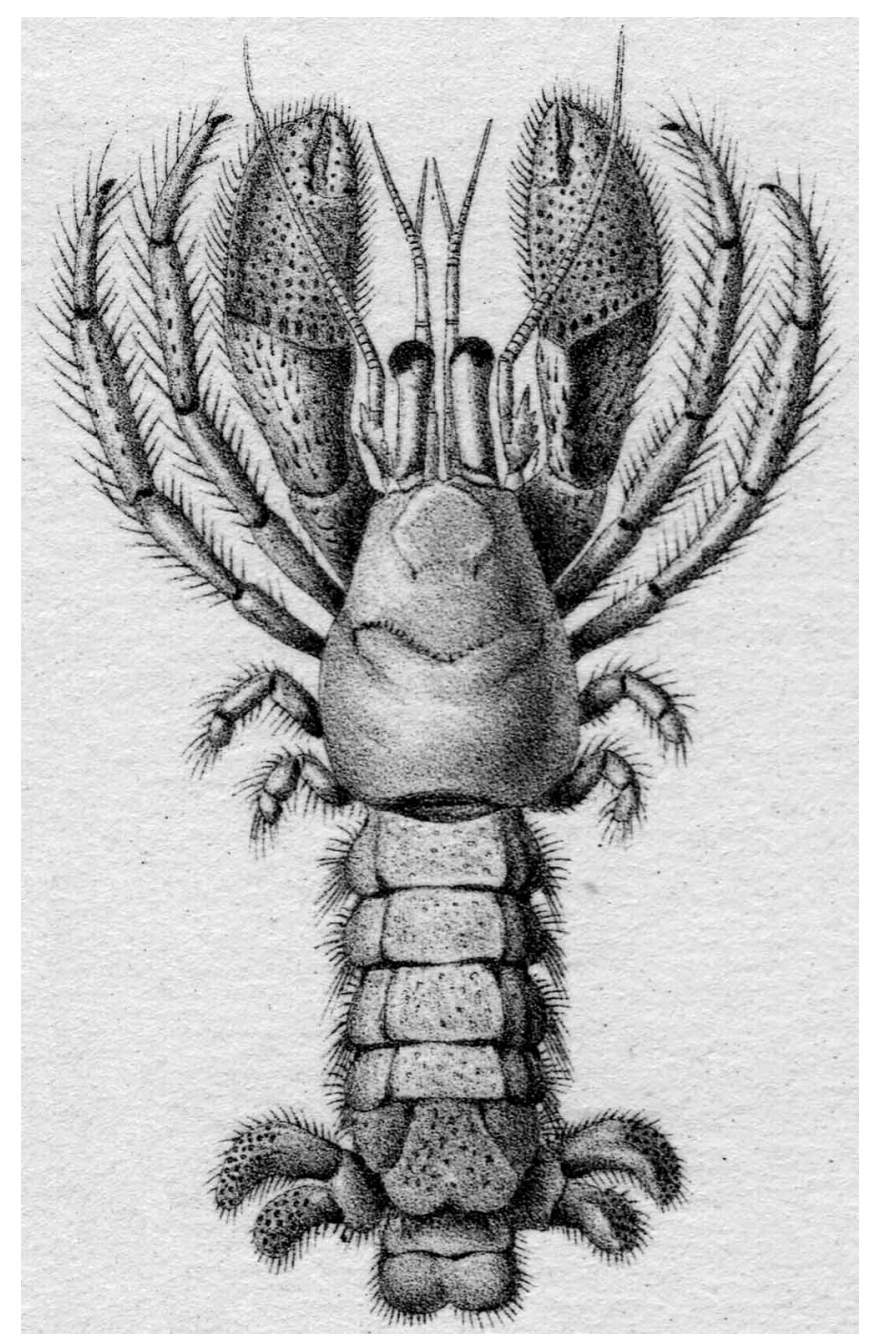

FIGURE 1. Pylocheles agassizii A. Milne-Edwards, 1880 (from A. Milne-Edwards \& Bouvier, 1893, pl. 1, fig. 1)

Prior to the monographic review of Forest (1987a) only 19 species of the Pylochelidae had been described and several of those were known only from their holotypes or just from their type localities. In addition to placing three of those species in synonymy with other known species, adding 23 new species and one new subspecies, Forest (1987a) redefined the existing five genera, proposed two additional new genera, and provisionally established six subfamilies. Only two species have been added since: Trizocheles pilgrimi Forest \& McLaughlin, 2000 from New Zealand and T. vaubanae McLaughlin \& Lemaitre, 2008 from New Caledonia.

Forest (1987a) considered the Pylochelidae a heterogeneous assemblage whose phylogenetically significant characters were difficult to identify. So distinctive were the majority of genera, that only Pylocheles A. Milne-Edwards, 1880 and Cheiroplatea Bate, 1888 appeared sufficiently closely related as to be grouped together in a single subfamily. That three of the other five subfamilies were monotypic was indicative of the vast array of distinct morphological attributes Forest (1987a) recognized during his detailed and thorough study. Forest suggested that with further investigation, it might be shown that each subfamily warranted full familial rank. 
In the 20 years subsequent to Forest's (1987a) monograph, the number of exploratory cruises undertaken by the Muséum national d'Histoire naturelle (MNHN) and the Office de la Recherche Scientifique et Technique Outre-Mer (ORSTOM), now the Institut de Recherche pour le Developpement (IRD) increased dramatically, and with them, the number of specimens of the Pylochelidae. The increased abundance of study material, together with the recent advances in cladistic methodology and computer generated analyses, has made it possible to evaluate the phylogenetic relationships among the genera and species of this family.

\section{Material and methods}

Ingroup taxa. This analysis of inter- and intrageneric relationships is based on 78 morphological characters. The ingroup consists of 41 of the 45 species and one subspecies currently recognized as valid taxa in the family. Because of the potential problems encountered by including taxa with missing data (Maddison 1993; Wilkinson 1995; Strong \& Lipscomb 1999) four species were omitted from the data matrix. Cheiroplatea scutata Ortmann, 1892 and Pylocheles (Bathycheles) macgilchristi (Alcock, 1905) are known from one and two specimens, respectively, none of which have been available for personal examination. The holotype and only representative of Trizocheles balssi (Stebbing, 1914) has been examined, but the specimen is dry and in poor condition with missing appendages. Although three specimens have been assigned to Pomatocheles stridulans Forest, 1987a, one is a megalopa and one a juvenile, both lacking chelipeds and ambulatory legs. The holotype is an adult, ovigerous female, but only the first two pleonal segments are present; thus several important character states are unknown for this taxon.

Despite the large numbers of specimens available for a few species, several species are still known from one or a few individuals. Therefore intraspecific variation has not been factored into the character states; morphological data for the matrix have been taken from the holotypes or lectotypes as often as possible. When species are known from a single specimen or sex, as are the cases for Cheiroplatea cenobita Bate, 1888, $C$. scutata and C. sternus Forest, 1987a; Pylocheles (P.) agassizi A. Milne-Edwards, 1880; Pomatocheles stridulans; Trizocheles albatrossi Forest, 1987a, T. balssi, T. longicaulis (Boas, 1926), T. loquax Forest, 1987a, T. manningi Forest, 1987a, T. moosai Forest, 1987a, and T. mutus Forest, 1987a, pleonal appendages of the opposite sex have been assumed to be typical of the genus.

Outgroup selection. Selection of outgroup taxa has been difficult because the sister group to the Pylochelidae has not been robustly identified. Faced with a similar problem when considering an outgroup for their phylogenetic appraisal of the Leptostraca, Walker-Smith \& Poore (2001) hypothesized an ancestor based on generally accepted crustacean evolutionary character transformations. Unfortunately, the direction of evolutionary transformations within the reptant Decapoda appears to be debatable. The Pylochelidae was considered paraphyletic by Richter \& Scholtz (1994), but monophyletic and basal to the rest of the Paguroidea and it in turn basal to the remainder of the Anomura by McLaughlin et al. (2007). The Anomura and its sister clade, the Brachyura, were thought to be the most highly evolved of decapod crustaceans by Scholtz \& Richter (1995), Schram \& Dixon (2003), Dixon et al. (2003), and Ahyong \& O'Meally (2004) but basal to the rest of the Reptantia by Porter et al. (2005). The branch support for the position of the Brachyura was low in the Porter et al. study; so we have chosen to polarize our characters using the thalassinid, Thalassina anomala (Herbst, 1804). The debate over the relationship of the Thalassinidea to the Anomura + Brachyura (Meiura of Scholtz \& Richter 1995) was succinctly summarized by Ahyong \& O'Meally (2004). We accept their conclusion that the homology of the linea thalassinica and linea anomurica represents a synapomorphy uniting these major taxa.

The accuracy of outgroup rooting is enhanced by including members of the closest group - the sister group. Forest (1987a) was of the opinion that the Diogenidae was most closely related to the Pylochelidae. McLaughlin et al.'s (2007) cladogram of anomuran relationships placed the Coenobitidae between the Pylochelidae and Diogenidae; however, because of the specialized adaptations to terrestrial environs exhibited by coenobitids, representatives of this family were not included in the outgroup. Instead, initially we selected 
three species as exemplars, representing the theoretically earliest derived genera of the family Diogenidae [Cancellus panglaoensis McLaughlin, 2008, Paguropsis typica Henderson, 1888, and Paguristes acanthomerus Ortmann, 1892]. However, the analysis done by Ahyong \& O'Meally (2004) placed the Pylochelidae, based on Pylocheles (Xylocheles) macrops Forest, 1987a, sister to the Galatheoidea, exclusive of the Aeglidae. For this reason, we also included their exemplar, Munida quadrispina Benedict, 1902, in the outgroup. Preliminary analyses explored inclusion of diogenids among the outgroups, but subsequent analyses were rooted to Munida and Thalassina.

Phylogenetic analysis. Parsimony analyses of the morphological data matrix were conducted under equal and implied weights (Goloboff 1993). In the latter approach we used concavity constants (k) ranging from 1 to 16 , that is, strong to relatively weak downweighting of homoplastic characters was implemented. The trees that resulted from both the weighted and unweighted procedures were subjected to strict consensus calculations. The weighted consensus tree was based on the topologies obtained from $\mathrm{k}$ values ranging from 5 to 10 (and 16). According to Goloboff et al. (2008) the preferred approach is to explore the effects of a range of "reasonable" k values (e.g. k=5 to k=16) on the tree structure. All parsimony analyses were run in TNT (Goloboff et al. 2003) using the traditional search approach with 2000 replications followed by TBR branchswapping, swapping 20 trees per replication and collapsing branches with zero length. Bremer support values (Bremer 1988, 1994) for the unweighted consensus trees were also inferred using TNT. TreeView (Page 1996) was used to display the phylogenetic trees. The data matrix (Table 1) originated in MacClade version 3 (Maddison \& Maddison 1992) and included 43 taxa, of which two made up the outgroup.

Characters and coding. Eighty-two characters were considered in the initial analysis, and a few of these were appropriate only to the Diogenidae. After exclusion of the diogenid genera from the analysis, the number of characters was reduced to 78 , and the states of some of the remaining characters were similarly reduced. Only the characters used with the restricted outgroup are included.

The morphology of pylochelids has been illustrated and described in detail by Forest (1987a), Forest \& McLaughlin (2000), and McLaughlin (2003). The list of characters and character states generally are self explanatory; however, clarifications of a few definitions and/or interpretations are necessary. Two terms in particular are herein interpreted differently from those used by Forest (1987a). The post-orbital lobe ("saillie postoculaire") of Forest is equivalent to the antennular lobe or spine in this analysis, whereas the lateral projection used here is synonymous with Forest's post-antennal lobe ("saillie postantennaire").

The shield is defined as the anterior portion of the carapace extending from the tip of the rostrum, midpoint of the rostral lobe, or midpoint of the anterior margin to the midpoint of cervical groove in pylochelids and is equivalent to the anterior carapace (including rostrum) in members of the outgroup. Additionally, we accept the interpretations of Snodgrass (1952) and Powar (1969) that the paguroid ocular peduncle consists of three segments rather than the two segments identified by Forest (1987a: 18). We have used the three types of fourth pereopod termination, subchelate, semichelate and chelate, as defined by Sandberg \& McLaughlin (1998), rather than the two, subchelate and chelate, used by Forest (1987a). As previously indicated, intraspecific variation was not considered, therefore the character states represent the attributes observed in the species representatives; no gap coding methods were employed

Dixon et al. (2003) "... could see no compelling reasons to differentiate the various types of lineae ...", scoring them simply absent or present. However, as pointed out by Forest (1987a) one linea, the linea transversalis of Boas (1926) and Pilgrim (1973) is an important diagnostic character in the Pylochelidae. This linea seems to be absent in the Thalassinidae. Although it has not been identified in anomurans other than paguroids, it may be equivalent to the accessory groove (t) of A. Milne-Edwards \& Bouvier (1894: figs. 10, 12). A linea interpreted herein as homologous is seen in Munida quadrispina and may also be identifiable with the lateral extension of the cervical groove depicted by Pike (1947) in his detailed study of Galathea Fabricius, 1793 or the continuation of the linea transversalis of Forest (1987a). Dixon et al. (2003), as well as Ahyong \& O'Meally (2004) followed Poore's (1994) suggestion that the linea thalassinica of thalassinoids and the linea anomurica of anomurans were synonymous.

McLaughlin et al. (2007) considered rudimentary gill structures nonfunctional and excluded them from 
gill formulae. The arthrobranchs of the third maxillipeds in species of Pomatocheles Miers, 1879 and Parapylocheles scorpio (Alcock, 1894) are substantially reduced, although the gill number typically is reported as 14 pairs.

TABLE 1. Data matrix.

111111111122222222233333333333444444444455555555556666666666777777777
Taxon \character no. $\quad 123456789012345678901234567890123456789012345678901234567890123456789012345678$

Thalassina anomala Munida quadrispina agassizii mortensenit miersi macrops cubensis incisus integer profundus crosnieri n. $\mathrm{sp} A$ laticauda cenobita mitoi stenurus pumicicola jeffreysii gaillardi scorpio sculptipes n. $\mathrm{sp} \mathrm{C}$

s. spinosus

s. bathamae

n. $\mathrm{sp} B$ pulcher pilgrimi longicaulis vaubanae Ioquax caledonicus albatrossi boasi gracilis moosai laurentae brachyops sakaii brevicaulis manningi mutus perplexus paradoxus
010100000000000000011000000000000001000010000012202230003000001000000001000000 000222010000000101210121100100001002220230010002222120000120011011202120202211 002201311000020001100121110120101112221230110000000101210111000002201001210211 002201311000020101100121110120101112221230110000000101210111000002201001211211 002201310000020101100121110120201000221120110000000111110111000012201001211210 000201310000020101000121110120201000221121110000000111120111000012301001210210 $002201311100120000000121110120201000111120110000000121110111000002201001 ? 11210$ 002201311100120000100121110120201000111121110000000221110111000012201001211210 002201311100120000100121110120201000111120110000000121110111000012201001211210 002201311100120000100121110120201000111120110000000121110111000012201001211210 002201310100120100100121110120201000111121110000000211110111000012201001212210 002101311100120000101121110120201000111121110000000221110111000012201001211210 002201200100110100001120110120101112111121110013201221211121000002201011212200 002201201100110100000120110120101112111230110010100121111121000012201011210200 002201201100110100000120200110101112121230110011101021110121000002201011211201 002201201100110100000120110120101112111230110013200121111121000012201011211200 002201201100110100000120110120101112111231110013211221111121000002201011212200 100202201000020111000101201101101100110120010000202111220121001012101011110111 101202201000020111200101200101101100110120110000101111210121001012001011110111 100002201011120200201021100000211000110101010100000221232111011102212021210110 002212100000120200001000001001111120220201010113201201230121010212001001011000 002212201000031201000120200000211022110201001011200211220121000112001001210111 002222201000031201000120200000211022110200001003222211220121000112001001210111 002222201000031201000120200000211022110200001003222211220121000112001001210111 001222201000031201000120200000211002110200001013200111220121000112001001210111 002222201000032201000120200000211022110200001013200211220121000112001001210111 002222201000031201000120200000211022110200001013210211220121000112201001210111 000222201000032201300120200000211022110201001003222211220121000112001001211111 002222201000031201000120100000211022110201001103222211220121001112201001210111 002212201000030201000120200000211020110201001013200211220121000112201001210111 002222201000030200000120200000211000110201001010200211220121000112001001210111 002222201000031201000120200000211022110200001110200211220121000112001001210111 001212201000031201000120200000211002110200001011200111220121000112201001210111 001212201000031201000120200000211002110200001011200111220121000112201001210111 002222201000030200000120200000211002110200001010200211220121000112101001210111 002222201000030201000120200000211002110200001010200211220121000112201001210121 001222201000030200000120200000211022110201001012202211220121000112001002212111 002212201000031201000120200000211022110200001012200211220121000112201001210111 001222201000031201000120200000211002110201001112200111220121000112201001210111 002222201000031201000120200000211020110201000110200211220121001112001001210111 002222201000031201000120200000211002020201000013200211220121000112201001210111 001212201000031201000121000000001020110201000010200111220121000112001001112001 001222201000031201000110200000011022110201010113200201220111101211101002012121 
While pleurobranchs are lacking in Thalassina anomala, the presence of pleurobranchs has been considered the ancestral condition by most carcinologists (e.g., Calman 1909; Martin \& Abele 1986; McLaughlin \& Lemaitre 1997; McLaughlin et al. 2007), and was viewed as a reversal in the Thalassinoidea by Poore (1994). Pleurobranch loss is considered the advanced state.

Although in the majority of paguroids the termination of the fifth pereopods is chelate, this termination is frequently subchelate in pylochelids; however, in certain taxa sexual dimorphism occurs. The states for this character are specifically for males because when dimorphism occurs, it is exhibited principally by males.

1. Arthrobranchs of third maxillipeds: well developed (0); reduced or absent (1).

2. Pleurobranch above fifth pereopod: present (0); absent (1).

3. Shield width: longer than broad (0); width approximately equal to length (1); broader than long (2).

4. Shield length: shorter than posterior carapace (0); approximately equal to posterior carapace (1); longer than posterior carapace (2).

5. Shield lateral margins: entire (0); with unarmed indentation (1); with armed indentation (2).

6. Linea transversalis: not apparent (0); apparent, not contiguous with cervical groove (1); apparent, contiguous with cervical groove at least centrally (2).

7. Rostrum: well developed, without subrostral spine (0); well developed, with subrostral spine (1); somewhat to moderately well developed (2); reduced or absent (3).

8. Post-antennular lobe or spine: absent (0); present (1).

9. Lateral projections: reduced, obsolete or absent (0); well developed (1).

10. Ocular peduncles: well developed (0); reduced (1).

11. Ocular segmental bases: widely separated (0); contiguous or nearly so (1).

12. Ocular peduncle armament: unarmed (0); armed with spines (1).

13. Corneas: normal (0); reduced or absent (1).

14. Ocular acicles: not developed (0); not apparent or present as plate of second segment fused with ultimate segment (1); present as plate-like on free penultimate segment (2); present with spine(s) on free penultimate segment (3).

15. Antennular peduncle length: elongate, overreaching distal margins of corneas by at least length of ultimate peduncular segment (0); overreaching but by less than length of ultimate segment (1); short, not overreaching distal margins of corneas (2).

16. Basal antennular segment: elongate, without spines (0); elongate, with 1 or more spines (1); short, usually with 1 or more spines (2).

17. Second antennular segment: unarmed (0); armed with 1 or more spines (1).

18. Antennal peduncle lengths: overreaching distal margins of corneas (0); not reaching to distal margins of corneas (1).

19. First antennal segment armature: 1 spine to dorsal row of small spines (0); dorsal row of small spines plus more elongate dorsodistal spine (1); no dorsal row of small spines, but prominently produced or spinose dorsodistal margin (2); unarmed (3).

20. Antennal acicle (scaphocerite): moderate to short (0); markedly reduced, vestigial or lost (1).

21. Epistome: unarmed (0); armed with 1 or more spines (1).

22. Mandibular cutting edge: chitinous (0); calcified (1).

23. Maxillulary endopod: external lobe articulated, recurved (0); external lobe articulated, not recurved (1); external lobe reduced or obsolete (2).

24. Maxillary scaphognathite: with 1 or more exceptionally long setae proximally on posterior lobe (0); without 1 or more exceptionally long setae proximally on posterior lobe (1).

25. First maxilliped: without exopodal flagellum (0); with non-articulated exopodal flagellum (1) with multiarticulated exopodal flagellum (2).

26. Second maxilliped endopod termination: simple (0) sub- semi- or completely chelate (1).

27. Second maxilliped exopod: unarmed (0); armed with one to several spines (1).

28. Second maxilliped epipod: present (0), absent (1). 
29. Third maxilliped termination: simple (0); semichelate (1); chelate (2).

30. Third maxilliped exopod: unarmed (0); with one or more spines (1).

31. Third maxilliped epipod: well developed (0); rudiment or scar (1); lost (2).

32. Crista dentata of third maxilliped: without accessory tooth (0); with accessory tooth (teeth) (1).

33. Pereopod 1: subchelate (0); chelate (1).

34. Chelae: not forming operculum (0); forming operculum (1).

35. Chela shape: subrectangular (0); subovate to ovate (1): subtriangular (2).

36. Chela dorsal surface: generally flattened or smoothly convex (0); with ridge(s) or crests (1); with granules, tubercles or spines (2).

37. Chela/carpal articulation: articulating in same plane (0); rotated approximately $30-45^{\circ}(1)$; articulating vertically (2).

38. Cheliped dactyl and fixed finger opening: vertical (0); oblique (1); horizontal (2).

39. Dactyl and fixed finger termination: corneous claws (0); calcified claws (1).

40. Palms of chelae with dorsomesial or upper margins: with elevated entire or scutellated ridges (0); with row(s) of tubercles (1); row(s) of spines (2).

41. Chela dorsolateral or lower margin: not delimited (0); with elevated entire or scutellated ridge(s) or lobes (1); with row(s) of tubercles (2); row(s) of spines (3).

42. Chela setation: with sparse setae (0); with moderate to abundant setae (1).

43. Carpal anterodorsal surface and margin: not prominently elevated (0); prominently elevated (1).

44. Carpal anterodorsal (dorsodistal) margin: unarmed (0); armed with granules, tubercles, spinules or spines (1).

45. Carpal stridulatory apparatus: absent (0); present (1).

46. Setation of carpi: with sparse setae (0); with moderate to dense setae (1).

47. Pereopod symmetry: second and third pereopods similar in shape and/or armature [exclusive of stridulatory apparatus] (0); second and third pereopods dissimilar in shape and/or armature [exclusive of stridulatory apparatus] (1).

48. Propodi of second pereopods: unarmed (0); with few to numerous protuberances, granules, tubercles or spinules (1); with 1 prominent dorsodistal spine (2); with row of few to numerous spines (3).

49. Carpi of second pereopods: unarmed or with only dorsodistal spine (0); with few numerous granules, tubercles or spinules (1); with few to numerous spines (2).

50. Propodi of third pereopods: unarmed or with small spine only at dorsodistal margin (0) with few to numerous protuberances, granules, tubercles or spinules (1); with few to numerous spines (2).

51. Carpi of third pereopods: unarmed or with spine only at dorsodistal margin (0); with few to numerous protuberances, granules, tubercles or spinules (1); with few to numerous spines (2).

52. Dactyl and propodal pereopod setation: lacking setae (0); with sparse setae (1); with moderate to abundant setae (2).

53. Sternite of male seventh thoracic segment (fourth pereopods): straight and undivided (0); straight and divided by transverse suture (1); compactly triangular (2); triangular, drawn out anteriorly to elongate median tip (3).

54. Fourth pereopod development: normal walking leg (0); reduced (1).

55. Fourth pereopod termination: simple (0); subchelate (1); semichelate (2); chelate (3).

56. Propodal rasp of fourth pereopod: not developed (0); consisting of single row of scales (1); consisting of 2 to several rows of scales (2); scales covering approximately half or more of lateral surface (3).

57. Sternite of male eighth thoracic segment (fifth pereopods): simple and plate-like (0); straight and rod-like (1); with prominent tubercle(s) (2); grooved (3).

58. Fifth pereopod development: normal walking leg (0); reduced (1).

59. Fifth pereopod termination in males: simple (0); subchelate (1); chelate (2).

60. Fifth pereopodal rasp: absent (0); present (1).

61. Pleon symmetry: pleomeres symmetrical (0); pleomeres asymmetrical (1). 
62. Pleonal tergal surfaces: weakly to well calcified, smooth (0): partially to completely calcified, sculptured (1); chitinous or membranous (2).

63. Pleonal pleura 2-5: moderately to well developed, at least covering bases of pleopods (0); poorly developed, not covering bases of pleopods (1); not developed (2).

64. Pleonal tergite 1: broad, subrectangular (0); triangular (1); reduced (2).

65. Pleomere 6 tergal shape: subrectangular (0); subquadrate to subcircular (1).

66. Pleomere 6 lateral margins: entire (0); with transverse incisions, sutures or indentations (1); with oblique incisions (2).

67. Pleomere 6 terminal margin: entire, unarmed (0); entire, with spines or spinules (1); with median incisions or concavity (2); with median area produced (3).

68. Male paired first pleopods: terminally spatulate (0); simple (1).

69. Male pleopods 3-5: paired, equally or subequally biramous (0); paired, endopods reduced or absent (1); paired, exopods reduced or absent (2).

70. Female first pleopods: present (0); absent (1).

71. Egg-bearing pleopods: both rami well developed (0); endopod reduced or absent (1); exopod reduced or absent (2).

72. Uropod symmetry: symmetrical, forming tailfan (0); symmetrical, not forming tailfan (1); asymmetrical (2).

73. Protopods of uropods: neither produced nor armed (0); produced posteriorly, unarmed (1); produced, with prominent posterior spine (2).

74. Uropodal endopods and exopods: without rasps (0); with rasps (1).

75. Telson shape: longer than broad (0); length approximately equal to width (1); broader than long (2).

76. Telson lateral margins: entire (0); with transverse indentations (1); with transverse sutures (2).

77. Telson posterior lobes: not delimited (0); delimited, symmetrical or nearly so (1); delimited, asymmetrical (2).

78. Telson terminal margin: entire or with slight median depression (0); with median concavity or cleft (1).

\section{Results}

The unweighted analysis (Bremer support values on the resolved nodes) with the diogenids excluded from the outgroup gave rise to 445 most parsimonious trees that were 311 steps long $(C I=0.40 ; R I=0.74 ; R C=0.30)$. The best fit (and homoplasy) score and the number of optimal trees for each $\mathrm{k}$ value implemented under implied weighting are shown in Table 2. As may be seen in Figure 2, the tree obtained from analyzing the characters as unweighted gave poor resolution. When the analysis was repeated with weighting against homoplasy (Goloboff et al. 2008), the results were significantly improved. Either the unweighted or the weighted tree (Figs. 2, 3) have three primary evolutionary branches in the Pylochelidae. The first includes the taxa of the subfamily Pylochelinae, the second is restricted to the Pomatochelinae, and the third contains the remaining taxa. Forest's (1987a) suggestion that each of the present subfamilies should be elevated to familial rank was not supported.

\section{Discussion}

A recent study by Goloboff et al. (2008) compared the performance of parsimony analyses of morphological characters under implied and equal weights, and found that the former outperformed the latter regardless of concavity constant used. This result, however, does not alleviate the need to explore the effects of different concavity values on the clade structure in trees obtained under implied weighting. Drawing firm conclusions about the existence of a taxonomic group that is only present for a given $\mathrm{k}$ value (Goloboff et al. 2008) is 
unwarranted. In our present study, we inferred trees for concavity constants ranging from 1 to 16 (Table 2 and Fig. 3). The consensus tree based on optimal phylogenies derived from $\mathrm{k}$ values between 5 and 16 was the same as that obtained from the best topologies inferred based on k constants ranging from 5 to 10 , suggesting that the clades shown in the strict consensus tree (Fig. 3) are robust to a wide degree range of downweighting strengths of homoplastic characters. However, in the strict consensus tree (not shown), based on all the implemented concavity constants (i.e. $\mathrm{k}=1$ through $\mathrm{k}=16$ ), two clades within Trizocheles collapsed into a polytomy and the structure of another group changed within the same clade.

TABLE 2. Summary of results obtained from the implied weighting analyses. Trees obtained with concavities 5-10 and 5-16 were the same, and were used to generate strict consensus trees. See Fig. 4.

\begin{tabular}{cllc}
\hline K -values & No. of Trees & Fit scores & Homoplasy scores \\
\hline 1 & 167 & 29.71 & 40.29 \\
2 & 2 & 38.05 & 31.95 \\
3 & 2 & 43.25 & 26.75 \\
4 & 46 & 46.88 & 23.12 \\
5 & 46 & 49.60 & 20.40 \\
6 & 46 & 51.71 & 18.28 \\
7 & 45 & 53.41 & 16.58 \\
8 & 46 & 54.82 & 15.18 \\
9 & 1 & 56.00 & 14.00 \\
10 & 1 & 57.01 & 12.99 \\
11 & 1 & 57.88 & 12.12 \\
12 & 1 & 58.63 & 11.36 \\
13 & 1 & 59.30 & 10.70 \\
14 & 1 & 59.90 & 10.10 \\
15 & 1 & 60.42 & 9.58 \\
16 & 1 & 60.90 & 9.10 \\
\hline
\end{tabular}

From these analyses, the monophyly of the Pylochelidae is not clearly confirmed. However, the three major branches that are recognized herein, strongly indicate evolutionary transformations. The Pylochelinae is sister to the remaining taxa, the latter sharing the synapomorphy of a continuous linea transversalis. Forest's (1987a) assessment of the Pylochelinae is corroborated to the extent that the subfamily contains the two genera Pylocheles and Cheiroplatea that share the synapomorphy, chelate termination of the third maxilliped. But the subdivision of Pylocheles into three subgenera is not as substantiated. In the Contree5K10(16) cladogram, only the subgenus Pylocheles (Pylocheles), i.e., P. (P.) agassizii and P. (P.) mortensenii, is clearly defined.

The Pomatochelinae is sister to Parapylochelinae + Cancellochhelinae, and defined by the apomorphy, spinose second antennal segments. The monotypic Parapylochelinae and Cancellochelinae are, as indicated, sister taxa, sharing several synapomorphies. However, the distinctiveness of the Parapylochelinae is substantiated by four unique apomorphies: the spinose and basally approximate ocular peduncles, the prominent tubercle on the sternite of the fifth pereopod, terminally simple male first pleopods, and the markedly reduced exopods of the female egg-bearing pleopods. Two apomorphies define the Cancellochelinae, the subrostral spine and the operculate chelae. While it is true that chelipeds forming an operculum is characteristic of species of Pylocheles (Pylocheles) and Cheiroplatea, the opercula formed are not homologous with the operculum of Cancellocheles. In these Pylochelinae, it is only the chelipeds that contribute to the opercula. In Cancellocheles sculptipes (Miyake, 1978) the operculum is formed in 
conjunction with the second pereopods. Mixtopagurus paradoxus A. Milne-Edwards, 1880, representing the monophyletic Mixtopagurinae, is unique within the family because of the asymmetry of its pleon, uropods and telson. Relationships among the taxa of the subfamily Trizochelinae primarily are unresolved in the strict consensus cladogram of unweighted characters (Fig. 2). However, when Trizocheles manningi Forest, 1987a and T. perplexus Forest, 1987a are excluded, the strict consensus tree based on optimal phylogenies derived from $\mathrm{k}$ values between 5 and 16 is the same as that obtained from the best topologies inferred based on $\mathrm{k}$ constants ranging from 5 to 10, suggesting that the clades shown in Figure 3 are robust to a wide range of downweighting strengths of homoplastic characters. Nonetheless, the relationships among the species $T$. pulcher Forest, 1987a, T. mutus Forest, 1987a, T. albatrossi Forest, 1987a and T. pilgrimi are unresolved. The remaining species assigned to the genus Trizocheles represent four distinct clades.

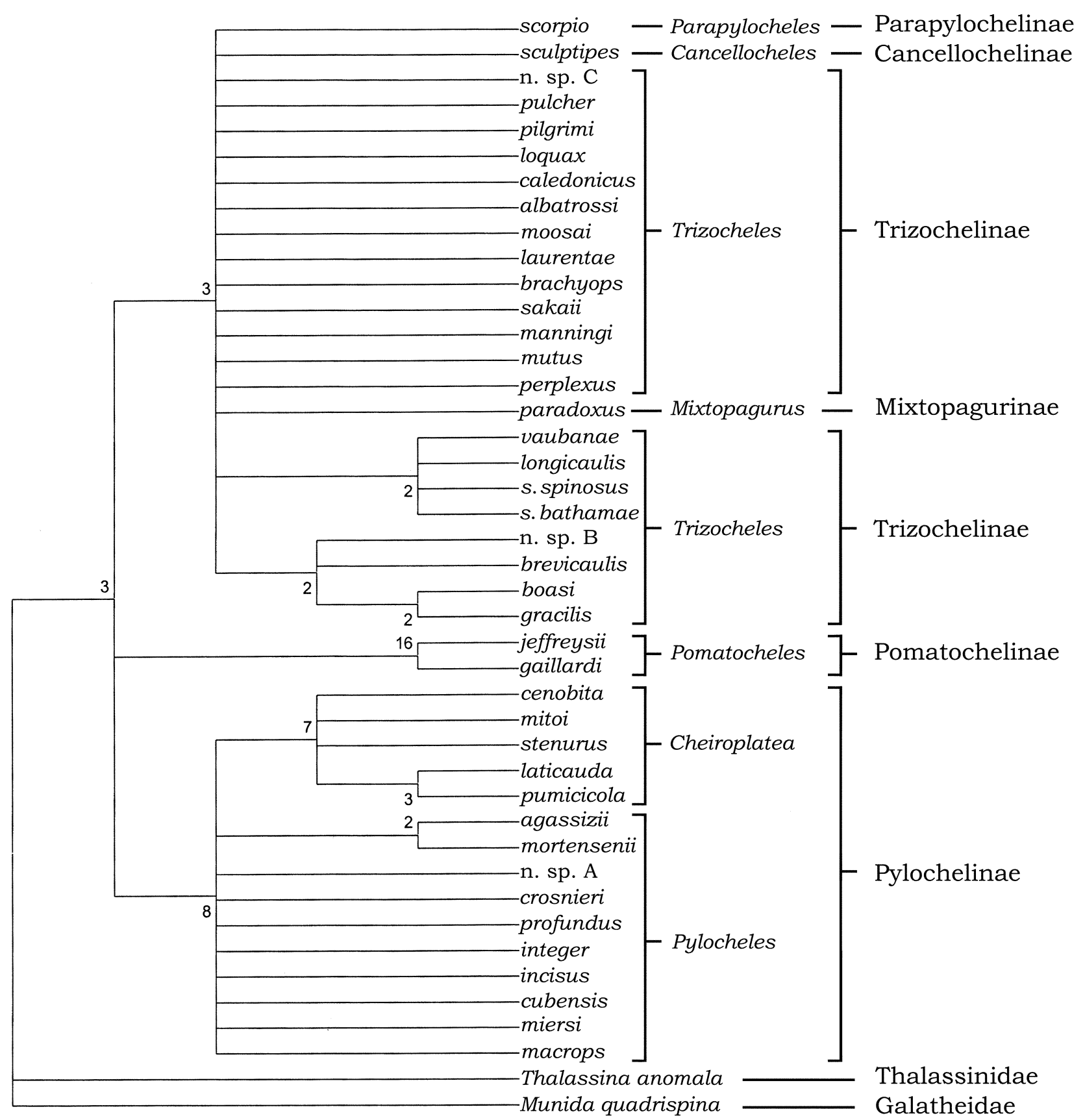

FIGURE 2. Strict consensus cladogram of 445 most parsimonious trees (length=311 CI =0.40; RI =0.74; RC =0.30) obtained from heuristic parsimony analyses of unweighted and unordered characters. Subfamily names as proposed by Forest (1987a) are indicated. Two taxa (Thalassinidae: Thalassina anomala, Galatheidae: Munida quadrispina) were used as the outgroup. Bremer support values are shown for the resolved nodes. 


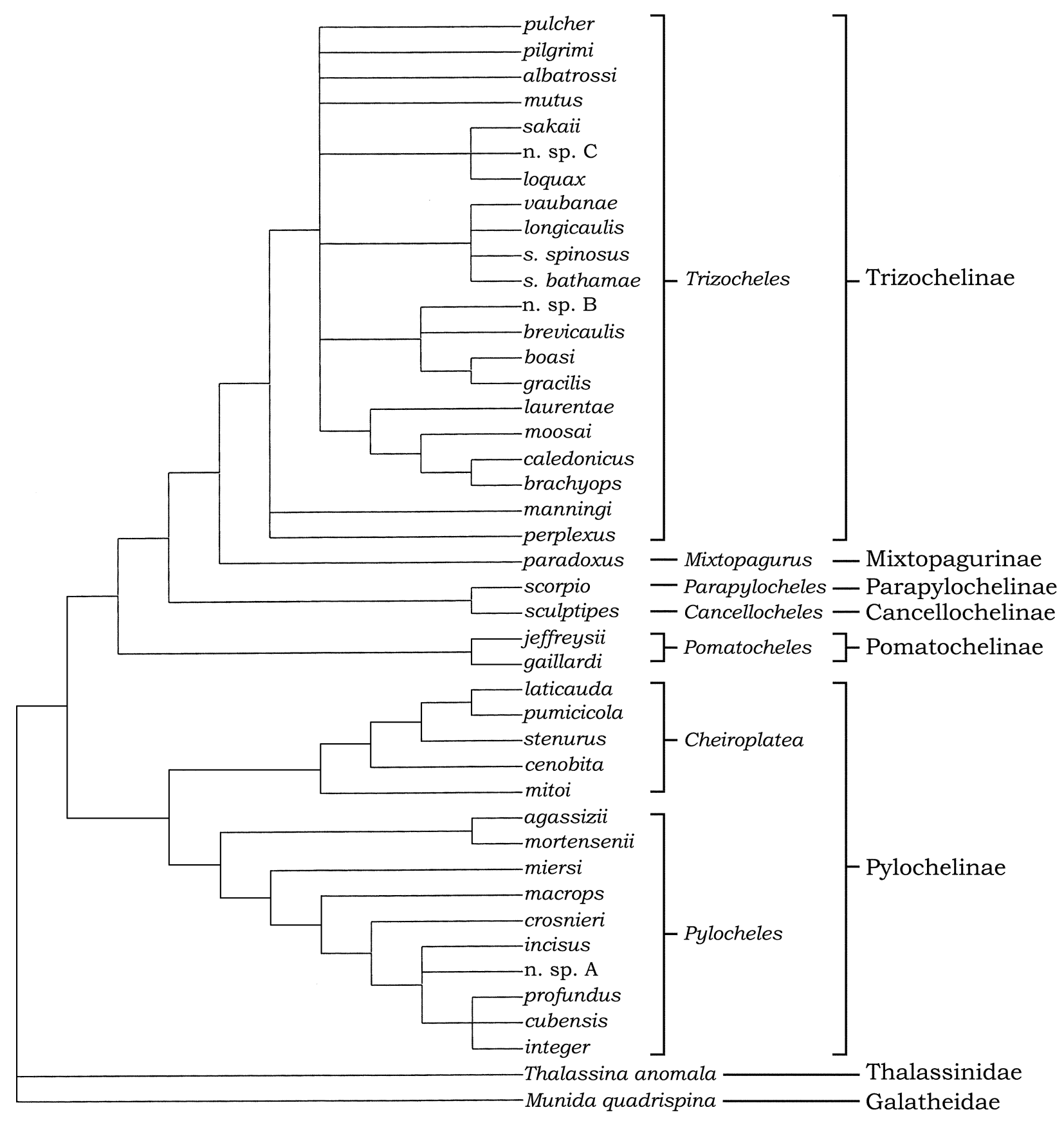

FIGURE 3. Strict consensus cladogram based on the optimal trees obtained under concavity values (i.e., k-values) ranging from 5 to 16. Subfamily names as proposed by Forest (1987a) are indicated. Two taxa (Thalassinidae: Thalassina anomala, Galatheidae: Munida quadrispina) were used as the outgroup. See Table 2 for fit and homoplasy scores.

Although larval data are very limited, what is available does add strength to the phylogenetic analysis. As discussed by McLaughlin \& Lemaitre (2008), the larvae of Pylocheles (Pylocheles) mortensenii Boas, 1926 and Pomatocheles jeffreysii differ so dramatically from one another and also from the larvae of Trizocheles spinosus spinosus (Henderson, 1888) and T. vaubanae that distinct subfamilial classification seems justified. Trizocheles s. spinosus and T. vaubanae are members of one of the Trizocheles clades. Regrettably, comparable data on larval development for either Cancellocheles sculptipes or Parapylocheles scorpio are not available to confirm or deny their apparent sister-group relationship as indicated by the phylogenetic analysis.

As our analyses have demonstrated, the Pylochelidae appears to consist of three distinct and divergent 
clades. Whether each should be treated as a taxonomically separate major taxon is beyond the scope of the present study. This question will be addressed in a subsequent investigation. However, our results may provide some insight into the seemingly untenable results of four recent studies of decapod phylogeny (Dixon et al. 2003, Schram \& Dixon 2003, Ahyong \& O'Meally 2004, Tsang et al. 2008). In these studies the Pylochelidae have consistently been aligned with the Galatheoidea (though with low nodal support) rather than the Paguroidea. The single pylochelid exemplar defining the Pylochelidae was identified only as Pylocheles sp. in the studies of Dixon et al. (2003) and Schram \& Dixon (2003), but specifically as Pylocheles (Xylocheles) macrops in the studies of Ahyong \& O'Meally (2004) and Tsang et al. (2008). Given the morphological and presumably genetic diversity now recognized in this family, it is perhaps understandable why the use of a single species as representative of all, gave a somewhat erroneous placement of the Pylochelidae among the Anomura.

\section{Acknowledgements}

This study, in part, is a scientific contribution from the Shannon Point Marine Center, Western Washington University. We thank Rose A. Gulledge for her assistance in preparing the figures.

\section{References}

Ahyong, S.T., \& O'Meally, D. (2004). Phylogeny of the Decapoda Reptantia: Resolution using three molecular loci and morphology. The Raffles Bulletin of Zoology, 52, 673-693.

Alcock, A. (1894). Natural history notes from H.M. Indian Marine Survey Steamer 'Investigator', Commander R.F. Hoskyn, R.N., commanding.- Series II., No. 1. On the results of deep-sea dredging during the season 1890-91. Annals and Magazine of Natural History, (6)13, 225-245.

Alcock, A. (1905). Anomura. Fasc. I. Pagurides. Catalogue of the Indian decapod Crustacea in the collections of the Indian Museum, 2, i-xi, 1-197. Indian Museum, Calcutta.

Bate, C.S. (1888). Report on the Crustacea Macrura dredged by H.M.S. Challenger during the years 1872-76. In: Report on the scientific results of the voyage of H.M.S. Challenger during the years 1873-76. Zoology, 24(52), i-xc, 1-942.

Benedict, J.E. (1902). Descriptions of a new genus and forty-six new species of crustaceans of the family Galatheidae, with a list of the known marine species. Proceedings of the United States National Museum, 26, 243-334.

Boas, J.E.V. (1926). Zur Kenntnis symmetrischer Paguriden. Konelige Danske Videnskabernes Selskabs Skrifter, Biologiske Meddelelser, 5(6), 1-52.

Bouvier, E.-L. (1940). Décapodes marcheurs. Faune de France, 37. Paul Lechevalier, Paris, 404 pp.

Bremer, K. (1988). The limits of amino acid sequence data in angiosperm phylogenetic reconstruction. Evolution, 42, 795-803.

Bremer, K. (1994). Branch support and tree stability. Cladistics, 10, 295-304.

Calman, W.T. (1909). Crustacea. Part VII, Apendiculata, fasc. 3. In: R. Lanchester (ed.), A treatise on Zoology. Adams and Charles Black, London, pp. i-vii, 1-346.

Dixon, C. J., Ahyong, S.T., \& Schram, F.R. (2003). A new hypothesis of decapod phylogeny. Crustaceana 76, 935-975.

Fabricius, J.C. (1793). Entomologia Systematica Emendata et Aucta, Secundum Classes, Ordines, Genera, Species, Adjectis Synonimis, Locis, Observationibus, Descriptionibus. 2, viii + 519 pp. Hafniae.

Forest, J. (1987a). Les Pylochelidae ou "Pagures symetriques" (Crustacea Coenobitoidea). In: Résultats des campagnes MUSORSTOM. Mémoires du Muséum National d'Histoire Naturelle, Série A, Zoologie, 137, 1-254.

Forest, J. (1987b). Ethology and distribution of Pylochelidae (Crustacea Decapoda Coenobitoidea). Bulletin of Marine Science, 41(2), 309-321.

Forest, J, \& McLaughlin, P.A. (2000). Superfamily Coenobitoidea. In: Forest, J., M. de Saint Laurent, P.A. McLaughlin, $\&$ R. Lemaitre, The marine fauna of New Zealand: Paguridea (Decapoda: Anomura) exclusive of the Lithodidae. NIWA Biodiversity Memoir, 114, 31-103.

Goloboff, P.A. (1993). Estimating character weights during tree search. Cladistics, 9, 83-91.

Goloboff, P.A, Farris, J., \& Nixon, K. (2003). T.N.T. Tree Analysis Using New Technology. (http://www.zmuc.dk/public/ phylogeny/tnt).

Goloboff, P.A., Carpenter, J.M., Arias, J.S. \& Esquivel, D.R.M. (2008). Weighing against homoplasy improves 
phylogenetic analysis of morphological data sets. Cladistics, 24, 758-773.

Henderson, J.R. (1888). Report on the Anomura collected by H.M.S. Challenger during the years 1873-76. Scientific Results of the Exploratory Voyage of HMS Challenger, (Zoology) 27, i-xi, 1-221. Her Majesty's Stationary Office, Edinburgh etc.

Herbst, J.F.W. (1804). Versuch einer Naturgeschichte der Krabben und Krebse etc. etc., 3(4), 1-49. Stralsund, Berlin.

MacDonald J.D., Pike, R.B. \& Williamson, D.I. (1957). Larvae of the British species of Diogenes, Pagurus, Anapagurus and Lithodes (Crustacea, Decapoda). Proceedings of the Zoological Society of London, 128, 209-257.

Maddison, W.P. (1993). Missing data versus missing characters in phylogenetic analysis. Systematic Biology, 42(4), $576-581$.

Maddison, W.P. \& Maddison, D.R. (1992). MacClade, version 3. Analysis of phylogeny and character evolution. Sinauer Associates, Inc., Sunderland, MA.

Martin, J.W. \& Abele, L.G. (1986). Phylogenetic relationships of the genus Aegla (Decapoda: Anomura: Aeglidae), with comments on anomuran phylogeny. Journal of Crustacean Biology, 6(3), 576-616.

McLaughlin, P.A. (1983). Hermit crabs-Are they really polyphyletic? Journal of Crustacean Biology, 3, 608-621.

McLaughlin, P.A. (2003). Illustrated keys to families and genera of the superfamily Paguroidea (Crustacea: Decapoda: Anomura), with diagnoses of genera of Paguridae. Memoirs of Museum Victoria, 60(1), 111-144.

McLaughlin, P.A. (2008). A new species of the hermit crab genus Cancellus (Decapoda: Anomura: Paguroidea: Diogenidae) from the PANGLAO Expeditions to the Philippine Islands. Raffles Bulletin of Zoology, Supplement 19, 83-90.

McLaughlin, P.A. \& Lemaitre, R. (1997). Carcinization - fact or fiction? I. Evidence from adult morphology. Contributions to Zoology, 67(2), 79-123.

McLaughlin, P.A. \& Lemaitre, R. (2008). Larvae of two species of Trizocheles (Decapoda: Anomura: Paguroidea: Trizochelinae), description of the adult of one, and preliminary implications of development on pylochelid phylogeny. Zootaxa, 1911, 52-68.

McLaughlin, P.A., Lemaitre, R., \& Sorhannus, U. (2007). Hermit crab phylogeny: A reappraisal and its "fall-out". Journal of Crustacean Biology, 27(1), 97-115.

Miers, E.J. (1879). On a collection of Crustacea made by Capt. H.C. St. John, R.N., in the Corean and Japanese Seas. Part I. Podophthalmia. With an appendix by Capt. H.C. St. John. Proceedings of the Zoological Society of London for the year $1879,18-61$.

Milne-Edwards, A. (1880). Report on the results of dredging, under the supervision of Alexander Agassiz, in the Gulf of Mexico, and in the Caribbean Sea, 1877, 78, 79, by the United States Coast Survey steamer "Blake", Lieut.Commander C.D. Sigsbee, U.S.N., and Commander J.R. Bartlett, U.S.N., commanding. VIII. Études préliminaires sur les Crustacés. Bulletin of the Museum of Comparative Zoology, Harvard College, 8(1), 1-68.

Milne-Edwards, A. \& Bouvier. E.-L. (1893). Reports on the results of dredging under the supervision of Alexander Agassiz, in the Gulf of Mexico (1877-78), in the Caribbean Sea (1878-79), and along the Atlantic coast of the United States (1880), by the U.S. Coast Survey Steamer "Blake", Lieut.-Com. S.D. Sigsbee, U.S.N., and Commander J.R. Bartlett, U.S.N., Commanding. 33. Description des Crustacés de la famille des Paguriens recueillis pendant l'Expédition. Memoirs of the Museum of Comparative Zoology, Harvard College, 14 (3), 1-172.

Milne-Edwards, A. \& Bouvier. E.-L. (1894). Considérations générales sur la famille des Galathéidés. Annales des Sciences Naturalles, Zoologie et Paléontologie, 16, 191-327.

Miyake, S. (1978). The crustacean Anomura of Sagami Bay: 1-200 (English), 1-161 (Japanese). Biological Laboratory, Imperial Household, Tokyo.

Ortmann, A. (1892). Die Decapoden-Krebse des Strassburger Museum, mit besonderer Berücksichtigung der von Herrn Dr. Doederlein bei Japan und bei den Liu-Kiu-Inseln gesammelten und zur Zeit im Strassburger Museum aufbewahrten Formen. IV. Die Abtheilungen Galatheidea und Paguridea. Zoologishen Jahrbüchern. Abtheilung für Systematik, Geographie und Biologie der Thiere, 6, 241-326.

Page, R.D.M. (1996). TreeMap. Software available from author.

Pike, R.B. (1947). Galathea. Liverpool Marine Biology Committee Memoirs, 34, i-viii, 1-138.

Pilgrim, R.L.C. (1973). Axial skeleton and musculature in the thorax of the hermit crab, Pagurus bernhardus [Anomura: Paguridae]. Journal of the Marine Biological Association of the United Kingdom, 53, 363-396.

Poore, G.C.B. (1994). A phylogeny of the families of Thalassinidea (Crustacea: Decapoda) with keys to families and genera. Memoirs of the Museum of Victoria, 54, 79-120.

Porter, M.L., Pérez-Losada, M. \& Crandall, K.A. (2005). Model-based multi-locus estimation of decapod phylogeny and divergence times. Molecular Phylogenetics and Evolution, 37, 355-369.

Powar, C.B. (1969). Musculature of the eyestalk in Crustacea. Acta Zoologica, 50, 127-141.

Richter, S. \& Scholtz, G. (1994). Morphological evidence for a hermit crab ancestry of lithodids (Crustacea, Decapoda, Anomala, Paguroidea). Zoologischer Anziger, 223(5/6), 187-219.

Sandberg, L. \& McLaughlin, P.A. (1998). Paguridea. Marine Invertebrates of Scandinavia, 10, 1-113.

Scholtz, G. \& Richter, S. (1995). Phylogenetic systematics of the reptantian Decapoda (Crustacea, Malacostraca). 
Zoological Journal of the Linnean Society, 113, 289-328.

Schram, F.R. \& Dixon, C. (2003). Fossils and decapod phylogeny. Contributions to Zoology, 72 (2-3), 169-172.

Snodgrass, R.E. (1952). The sand crab Emerita talpoida (Say) and some of its relatives. Smithsonian Miscellaneous Collections, 117(8), 1-34.

Stebbing, T.R.R. (1914). South African Crustacea (Part VII of S.A. Crustacea, for the Marine Investigations in South Africa). Annals of the South African Museum, 15, 1-55.

Strong, E.E. \& Lipscomb, D. (1999). Character coding and inapplicable data. Cladistics, 15(4), 363-371.

Tsang, L.M., Ma, K.Y., Ahyong, S.T. Chan, T.-Y. \& Chu, K.H. (2008). Phylogeny of Decapoda using two nuclear protein-coding genes: Origin and evolution of the Reptantia. Molecular Phylogenetics and Evolution, 48, 359-368.

Walker-Smith, G.K. \& Poore, G.C.B. (2001). A phylogeny of the Leptostraca (Crustacea) with keys to the families and genera. Memoirs of Museum Victoria, 58(2), 383-410.

Wilkinson, M. (1995). A comparison of two methods of character construction. Cladistics, 11, $297-308$. 